\title{
Ammonium Sorbed to Zeolite Is Partly Available to Wheat in the First Growth Cycle
}

\author{
Bente Foereid ${ }^{1, *}$, Emilio Alvarenga ${ }^{1,2}$, Julia Szocs ${ }^{1}$ and Marianna Makadi ${ }^{3}$ \\ 1 Environment and Natural Resources, Norwegian Institute of Bioeconomy Research, P.O. Box 115, \\ N-1431 Ås, Norway; ehacas@gmail.com (E.A.); juliaszocs@yahoo.com (J.S.) \\ 2 Present address: Smart Symbiotech AS, Vangsveien 10, 1814 Askim, Norway \\ 3 University of Debrecen, Research Institute of Nyíregyháza, P.O. Box 12, 4400 Nyíregyháza, Hungary; \\ makadim@gmail.com \\ * Correspondence: Bente.Foreid@nibio.no; Tel.: +47-40105960
}

Received: 31 January 2019; Accepted: 28 February 2019; Published: 5 March 2019

\begin{abstract}
Sorption could be a way to concentrate nutrients in diluted waste streams to bring more nutrients back to agriculture. However, the sorbed nutrients must be plant available. The aim of this work was to investigate how plant available nitrogen $(\mathrm{N})$ added sorbed to zeolite and is compared to conventionally added $\mathrm{N}$. First, ${ }^{15} \mathrm{~N}$ labelled ammonium was sorbed to a sorbent, zeolite, in an aqueous solution. Then, the fertilizer effect was compared to the ammonium fertilizer and added the conventional way, with and without zeolite. A pot experiment with two soil types (chernozem and sandy soil) and wheat as test crop was used. Results indicated that the fertilizer effect of sorbed ammonium in the first growth cycle is about $50 \%$ of ammonium added conventionally. The sorbent itself had a positive effect in sandy soil, but not in chernozem. $\mathrm{N}$ uptake without added $\mathrm{N}$ was higher in chernozem than in sandy soil and more $\mathrm{N}$ from fertilizer was left in the soil after the experiment in the chernozem than in the sandy soil. In conclusion, ammonium added sorbed is plant available to some extent, but less so than conventionally added ammonium.
\end{abstract}

Keywords: sorption; zeolite; nitrogen; ammonium; nutrient availability

\section{Introduction}

To develop a circular economy, reduce greenhouse gas emissions, energy use, and resource mining, nutrients in waste streams should be recovered and brought back to agriculture to replace mineral fertilizers as much as possible [1]. Many waste streams contain diluted nutrients (e.g., sewage, digestate from biogas production, animal manure, and other agricultural waste streams and various waste streams from industry and food processing). These nutrients should ideally be returned to agriculture, but there are several obstacles to this [2], such as high water content making transport expensive. Some water can be removed by dewatering, but most of the soluble and plant available nutrients will be found in the liquid phase. Many waste streams contain nitrogen $(\mathrm{N})$ as an ammonium that is easily lost as ammonia during handling. Fixing as much as possible ammonium and get in the dry fraction is therefore a priority as well.

Sorption processes are widely used to remove pollutants from wastewaters (see: Crini and Badot) [3]. Examples of widely used sorbents are activated carbon, other charred materials, some minerals like zeolite, and clay like minerals (e.g., bentonite, vermiculite). It is possible to use some sorbents to remove nutrients from liquid waste streams. Cation exchange is the most common and removal of ammonium has been reported by many authors [4-10], although there is only one report on ammonia removal from the gas phase [11]. The sorbtion of ammonium is known to be strong and thermally stable [12,13]. 
Sorption processes are also important in nature, i.e., in soils. Soils can be regarded as weak cation exchangers and there are more cation exchange sites (cation exchange capacity) in clay soils than in sandy soil; organic matter also increases cation exchange capacity. As nutrient retention in soil is mostly sorption, soils may be improved by adding sorbents. This is particularly true for light sandy soil that have few sorption sites. The most commonly suggested candidate is biochar and there is a lot of literature on this subject. Biochar have been promoted as soil amendments that in addition to sequester carbon (C) could have some agronomic advantages when applied to soil [14-19]. Most of the beneficial effects of biochar in soil are probably related to sorption properties [14], mainly through cation exchange capacity [20]. Biochar has also been found to have the strongest effect on light-textured soil [21]. There are also some (less extensive) researches that deal with the additions of other sorbents to soil. Bentonite has been applied as a soil amendment and appears to have beneficial effects on soil structure in light soils [22] and improve crop yield [23]. It has also been shown to change enzyme activities in soil [24]. However, bentonite appears to bind some water, and this can be harmful for crop growth in dry climates when not irrigated. Zeolite has also been tried as a soil amendment [25]. The results suggest that zeolite additions increase nutrient retention and can change soil water holding capacity, infiltration rate, and hydraulic conductivity, although the direction of change depends on soil and zeolite properties.

One way to concentrate nutrients in wastewater and waste with high water content would be to sorb it to cheap and abundant sorbents before dewatering $[5,6]$. The sorbent loaded with nutrients can then be applied to agricultural soils as fertilizer [26]. However, there are few studies to characterize the availability of sorbed nutrients to support plant growth. Ammonium sorbed to zeolite was shown to be a good slow release fertilizer for kale [27] and spinach [28], but uptake was not quantified in those studies. Perrin et al. [29] found higher uptake of ammonium added sorbed than conventionally in a field experiment with maize. Sorbed gaseous ammonia [11] has been shown to be plant available [30], but this study did not compare the availability of the sorbed $\mathrm{N}$ to that applied in the conventional way. That is done in this study, where we use ${ }^{15} \mathrm{~N}$ as a tracer to compare plant availability of ammonium added sorbed to zeolite with ammonium applied using the conventional method in two different soil types (chernozem and sandy).

\section{Materials and Methods}

\subsection{Soil and Zeolite}

Two soil types, one chernozem and one sandy soil, were used in the experiment. Both soil types were collected in May 2016. The chernozem was collected in Tiszavasvari $\left(21^{\circ} 24^{\prime} 36.01 \mathrm{E}, 47^{\circ} 57^{\prime} 47.94 \mathrm{~N}\right)$. The sandy soil was collected in an arable field of Nyiregyhaza $\left(21^{\circ} 42^{\prime} 08.57 \mathrm{E}, 47^{\circ} 59^{\prime} 13.71 \mathrm{~N}\right)$, in Hungary. On the chernozem rape seed was grown and the previous winter wheat was sown. On the sandy soil red millet was sown in 2016, while oat was grown in the previous year. Both sites were plowed; fertilizer was applied as recommended each year. Results of analysis of both soils (using Eurofins standard methods) are given in Table S1.

The zeolite was of the Mahdi type, specific surface area (BET method) $33.14 \mathrm{~m}^{2} \mathrm{~g}^{-1}$, composed of Montmorillonite (30-45\%), Varco (30-40\%), kaolinite (10-15\%), Feldspar (3-7\%), and Calcite (1-2\%). Element concentration was measured by X-ray fluorescence (weight \%): O $65.6 \pm 1.8$, Si $25.5 \pm 1.4$, $\mathrm{Al} 4.1 \pm 1.1$, Fe $1.1 \pm 0.4, \mathrm{~K} 2.6 \pm 0.9, \mathrm{Ca} 0.9 \pm 0.3$, and $\mathrm{Mg} 0.2 \pm 0.07$.

\subsection{Zeolite and Labelled $N$}

${ }^{15} \mathrm{~N}$ labelled ammonium sulfate was used. Solutions of $1 \mathrm{~g} \mathrm{~L}^{-1} 5 \%$ labelled ammonium sulfate were prepared and $16 \mathrm{~g} \mathrm{~L}^{-1}$ zeolite was added. The solution was stirred for $100 \mathrm{~h}$ and the amount of sorbed was assessed by measuring the remaining concentration in the solution using an electrode Thermo Scientific Orion model 9300BNWP (93 Series) and its reference ion selective electrode (ISE) 900,200 Sure-Flow D/J ${ }^{\circledR}$ coupled to a Thermo Scientific Orion STAR SERIES pH/ISE-meter 
(ThermFisher Scientific, Waltham, MA, USA). The zeolite with sorbed ammonium was filtered by vacuum filtration at -450 mbar using filter paper with a particle retention of $12-15 \mu \mathrm{m}$ and dried. It was found that the sorption capacity was $18.16 \mathrm{mg} \mathrm{NH}_{4}{ }^{+}-\mathrm{N} \mathrm{g}^{-1}$ zeolite. This was used to calculate the amounts of zeolite to add to the treatments with zeolite in the plant growth trial.

\subsection{Growth Trials and Treatments}

The treatments were: no added $\mathrm{N}(\mathrm{ON}), \mathrm{N}$ added sorbed to zeolite as described (Nsorb), same amount of $\mathrm{N}$ and zeolite added, but just mixed (N+zeo), and same amount of $\mathrm{N}$, but no zeolite $(\mathrm{N})$. The amounts were $0.2 \mathrm{~g} \mathrm{~N}$ to all pots receiving $\mathrm{N}$ fertilizer and $11.67 \mathrm{~g}$ zeolite to all pots receiving zeolite (Nsorb and N+zeo). All pots received $0.6 \mathrm{~g} \mathrm{~K}_{2} \mathrm{SO}_{4}$ and $0.25 \mathrm{~g} \mathrm{KH}_{2} \mathrm{PO}_{4}$ as fertilizer in addition to any $\mathrm{N}$ treatment. Amounts of N, P, and K added were based on NIBIO recommendation in fertilizer handbook [31]

All treatments were repeated on both soil types and there were three replicates. As a test plant, wheat (variety "Bjarne") was used for the experiment. The pot size was $2 \mathrm{~L}$. Thirteen seeds were sown in each pot, thinned to 10 shortly after germination. Pots were watered to maintain water content between half field capacity and full field capacity. The temperature in the greenhouse was kept at or above $20 / 12{ }^{\circ} \mathrm{C}$ day/night and $16 \mathrm{~h}$ day.

Plants were allowed to grow until after ear emergence ( 52 days). Then aboveground plants were harvested and plant material was dried at $70{ }^{\circ} \mathrm{C}$ and weighed. Soils were sampled from each pot and air dried for analysis of total $\mathrm{N}$ and ${ }^{15} \mathrm{~N}$ signature. In addition, samples were taken from each soil before growth.

\subsection{Analyses}

Dry plant and soil samples were grinded to a fine powder and subsamples were weighed for analysis of total $\mathrm{N}$ and $\mathrm{C}$ and ${ }^{15} \mathrm{~N}$ signature. Total $\mathrm{N}$ and $\mathrm{C}$ was measured on $\mathrm{CHN}$ analyzer (Elementar Vario EL with TCD decetor, Langenselbold, Germany). ${ }^{15} \mathrm{~N}$ signature was measured in UC Davis' Stable Isotope Laboratory. Isotope ratio in plant and soil samples were measured directly on grinded samples.

\subsection{Calculations and Statistics}

$\mathrm{N}$ recovery was calculated using a mixing model based on $5 \%$ label in added fertilizer $\mathrm{N}$ and meausured natural abundance values in unlabelled plant and soil. Mineral fertilizer equivalent (MFE) for the $\mathrm{N}+$ zeo and Nsorb treatments were calculated based on ${ }^{15} \mathrm{~N}$ uptake and the $\mathrm{N}$ only treatment as $100 \%$ for each soil type.

The statistics was done with a minitab v15, and 5\% was used as the significance level. One- and two-way ANOVA's were applied to compare treatments. The treatment with no $\mathrm{N}$ was excluded from these analyses as the aim was to compare different ways of adding N. Individual treatments were also compared using post hoc tests and t-tests, when appropriate.

\section{Results}

\subsection{Biomass and N Uptake}

Figure 1 shows biomass and $\mathrm{N}$ uptake. In the sandy soil, the treatment with $\mathrm{N}$ sorbed to zeolite had significantly less biomass than the treatment where $\mathrm{N}$ and zeolite were both added without sorption; it was the treatment that did best overall. In addition, all were significantly different from the treatment without any $\mathrm{N}$ added. In the chernozem, the treatment with $\mathrm{N}$ sorbed to zeolite had significantly less biomass than both the other treatments that received $\mathrm{N}$, with and without zeolite. The treatment with $\mathrm{N}$ added sorbed to zeolite was not even significantly different from the no $\mathrm{N}$ treatment. $\mathrm{N}$ uptake showed a similar pattern to biomass (Figure 1). 


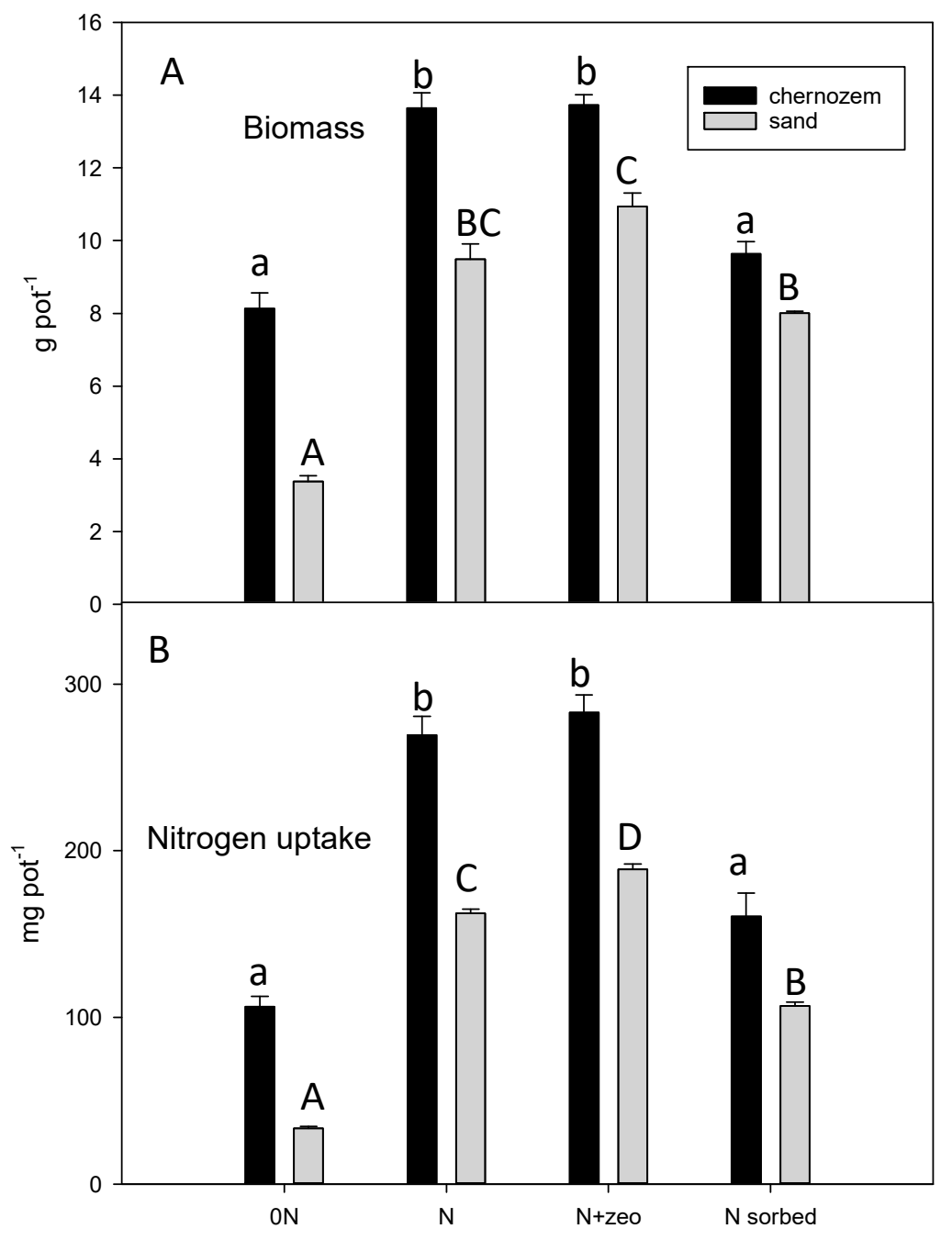

Figure 1. Plant aboveground biomass (A) and $\mathrm{N}$ uptake (B) at harvest. Error bars are standard deviation $(n=3)$. $0 \mathrm{~N}$ : no Nitrogen; $\mathrm{N}$ : $\mathrm{N}$ fertilizer; $\mathrm{N}$ fertilizer with zeolite without sorption; $\mathrm{N}$ sorbed to zeolite. Letters show which treatments are significantly different for sandy soil (capital letters) and chernozem (small letters).

\subsection{N Uptake from Soil and Fertilizer}

Lower $\mathrm{N}$ uptake from fertilizer in no $\mathrm{N}$ and Nsorb was not compensated by a higher uptake from soil (Figure 2). The $0 \mathrm{~N}$ treatment took up less $\mathrm{N}$ from soil as well than the treatments that received fertilizer with $\mathrm{N}$ as well. There was a significant effect of both soil types and treatment with the addition of $\mathrm{N}$ on $\mathrm{N}$ uptake, but the interaction was not significant $(p=0.067)$. Of the fertilizer treatments, it was the treatment with $\mathrm{N}$ added sorbed that had a lower uptake from fertilizer than the other treatments that received $\mathrm{N}$.

Uptake from soil and fertilizers were also assessed separately, based on the ${ }^{15} \mathrm{~N}$ signature. There was a significant effect of both soil type and fertilizer addition treatment on uptake from soil and also a significant interaction. Only fertilizer addition treatment had a significant effect on uptake from fertilizer, but neither the effect of soil nor the interaction was significant. The total recovery of ${ }^{15} \mathrm{~N}$ in plant shoot was above or around $50 \%$ when $\mathrm{N}$ was added not sorbed and around $25 \%$ when it was added sorbed (Table 1). In both cases it was somewhat higher in the sandy soil than the chernozem. 


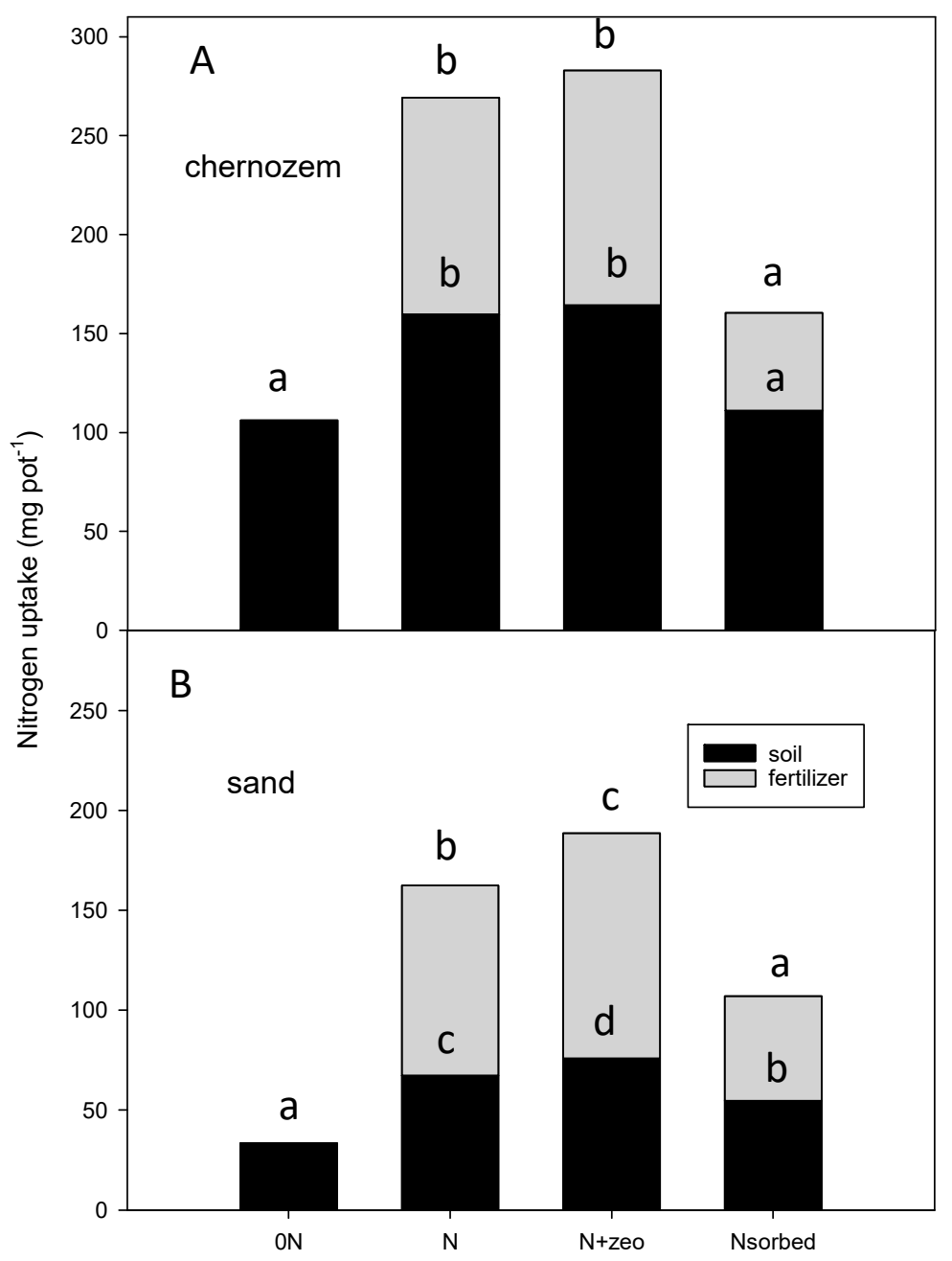

Figure 2. $\mathrm{N}$ uptake from soil and fertilizer was calculated using the ${ }^{15} \mathrm{~N}$ signature data for chernozem (A) and sandy soil (B). 0N: no Nitrogen; N: N fertilizer; $\mathrm{N}$ fertilizer with zeolite without sorption; $\mathrm{N}$ sorbed to zeolite. Letters show significant differences.

Table 1. ${ }^{15} \mathrm{~N}$ recovery in plant shoot (\%) and mineral fertilizer equivalent (\%) based on MFE for $\mathrm{N}=100 \%$. Standard error in brackets $(n=3)$. 0N: no Nitrogen; N: N fertilizer; N fertilizer with zeolite without sorption; N sorbed to zeolite.

\begin{tabular}{cccc}
\hline & $\mathbf{N}$ & $\mathbf{N}+$ zeo & Nsorb \\
\hline${ }^{15}$ N recovery & & & \\
Chernozem & $54.8(2.28)$ & $59.4(2.20)$ & $24.8(2.16)$ \\
Sandy soil & $47.6(0.72)$ & $56.4(1.01)$ & $26.2(0.51)$ \\
\hline MFE & & & \\
Chernozem & & 108.3 & 45.3 \\
Sandy soil & & 118.5 & 55.1 \\
\hline
\end{tabular}

MFE measures what percent of the $\mathrm{N}$ uptake was from fertilizer in each treatment compared to that with conventional $\mathrm{N}$ application. MFE of the sorbed $\mathrm{N}$ was around $50 \%$, which was somewhat higher in the sandy soil than in the chernozem (Table 1). The MFE of N and zeolite was above a 100\% showing that zeolite in itself had a positive effect, again higher in the sandy soil (Table 1). 


\subsection{Soil $N$}

The total $\mathrm{N}$ and $\mathrm{C}$ content in the soil changed very little during the experiment (data not shown), but a much larger fraction of the added fertilizer was found in the chernozem than the sandy soil at the end of the experiment (Figure 3). Only a small fraction of the $\mathrm{N}$ found in the soils at the end of the experiment was derived from the added fertilizer, but this fraction was much larger in the chernozem than in the sandy soil (Figure 3). In the sandy soil, only negligible amounts of $\mathrm{N}$ from fertilizer in all treatments was left at the end of the experiment. There was a significant effect of soil type and not of $\mathrm{N}$ addition and the interaction between them was significant. In the chernozem, there was a tendency towards a smaller fraction found in the soil when $\mathrm{N}$ was added sorbed, in the sandy soil the opposite tendency was found (Figure 3). In the sandy soil, effectively all $\mathrm{N}$ from fertilizer was used up except in the treatment where $\mathrm{N}$ was sorbed (Figure 3).

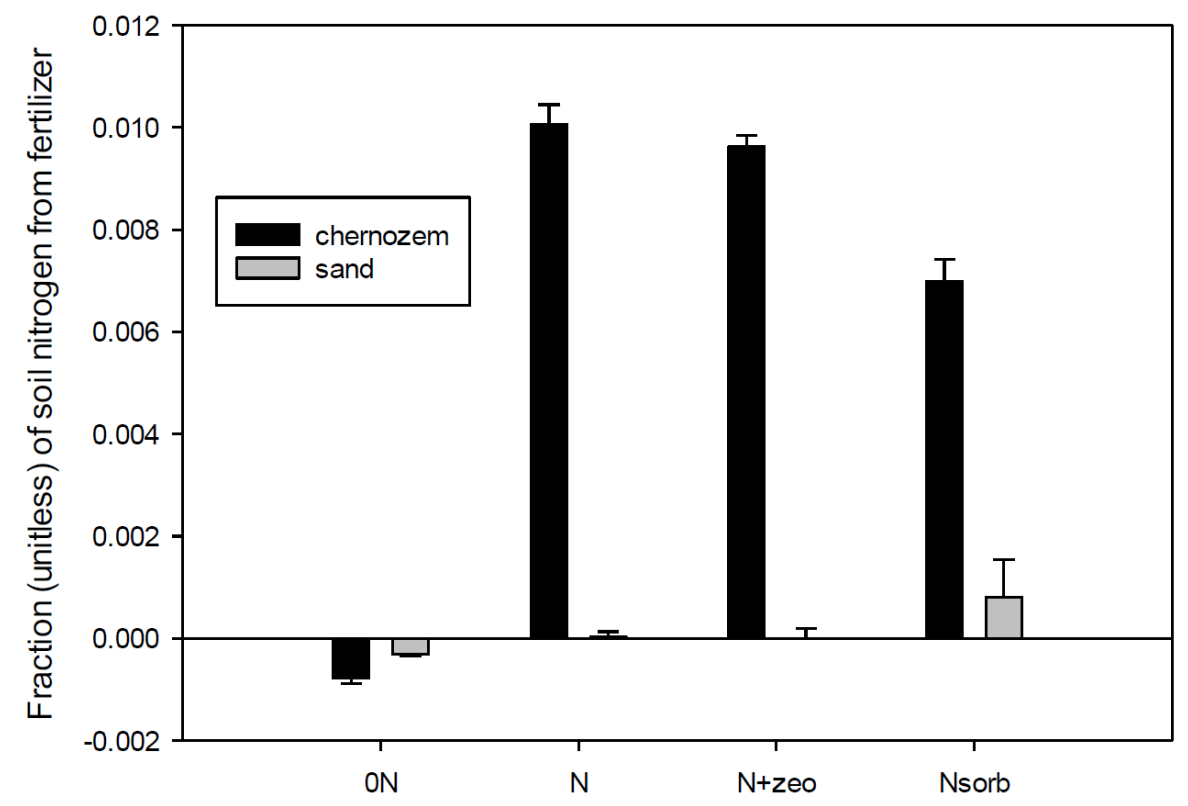

Figure 3. Fraction of the total $\mathrm{N}$ in the soil that originated from the added fertilizer, calculated from ${ }^{15} \mathrm{~N}$ signature. Error bars are standard deviation $(n=3)$. $0 \mathrm{~N}$ : no Nitrogen; N: N fertilizer; $\mathrm{N}$ fertilizer with zeolite without sorption; $\mathrm{N}$ sorbed to zeolite.

\section{Discussion}

Nitrogen sorbed to zeolite was less plant available than $\mathrm{N}$ added as a fertilizer without sorption. The reason may be that some of the ammonium was tightly bound inside the zeolite. The only similar study known to us was done by Taghizadeh-Toosi et al. [30], where labelled gaseous ammonia was sorbed to biochar and it was found that labelled $\mathrm{N}$ was recovered in the plant. Furthermore, in our study, labelled $\mathrm{N}$ was recovered in the plant, but the recovery was only about half of that found when $\mathrm{N}$ was applied the conventional way. Taghizadeh-Toosi et al. [30] found recovery rates in the shoot of $10.9-26.1 \%$. We found recovery rates of the sorbed $\mathrm{N}$ within that range as well (24.8-26.2\%). It was difficult to compare those figures directly, as different plant species and ages were used. However, comparison of plant uptake from sorbents with different sorption properties would be interesting. One other study has looked at desorption of nutrients from wastewater in soils without plants [26]. Here, it was found that the sorbent (clinoptilolites) released ammonium (and other ions) slowly over many watering cycles. The fraction of added ammonium released was not quantified. As this was a pot experiment, losses by leaching were excluded. However, Perrin et al. [29] found higher N uptake when $\mathrm{N}$ was added sorbed to zeolite than when added conventionally in a field experiment, not a pot experiment such as ours. The reason for this was probably lower leaching losses. This study also used maize, which takes up more $\mathrm{N}$ later in the growth cycle than wheat, where the slow release 
nature of the sorbed $\mathrm{N}$ could be more beneficial for crops with a longer period of nutrient uptake. Our experiment was a pot experiment and there were no leaching losses.

Zeolite in itself had a positive effect on growth and $\mathrm{N}$ uptake in the sandy soil, but not in the chernozem. Previous field experiments have indicated that additions of bentonites can have positive effects in sandy soil [22,23]. Chernozem has many sorption sites, and therefore it is not surprising that addition of sorbent had no effect there. There may be many mechanisms for how sorption can improve plant growth. Leaching has already been discussed, but it is not the mechanism here, as there were no leaching losses. Reduced gaseous losses is another possible mechanism.

Plants did not compensate for lower or no uptake from fertilizer by taking up more $\mathrm{N}$ from the soil; in fact, the opposite tendency was observed. This may indicate that reduced growth and vigor caused by $\mathrm{N}$ starvation may lead to a lower capacity for uptake. $\mathrm{N}$ starved plants may also put a larger fraction in belowground parts [32-34] and these were not quantified in this study. The results of the $\mathrm{N}$ uptake (Figure 2) showed that the MFE values were independent from the soil type but that the form of the added nutrient had a significant effect on it.

Some of the $\mathrm{N}$ from fertilizer was found in the chernozem at the end of the experiment, whilst this was negligible in the sandy soil. This may indicate that soils rich in organic matter have faster nutrient cycling and may therefore be better able to supply the plant with nutrients when it needs it, as well as taking $\mathrm{N}$ up in microbial biomass [35]. The sandy soil depends more on added $\mathrm{N}$ and it cannot be retained in the soil. The fact that some of the sorbed $\mathrm{N}$ from fertilizer was found also in the sandy soil at the end of the experiment but not in the other treatments further supported the conclusion that some of the $\mathrm{N}$ added sorbed was unavailable to plants in the studied early periods. In the chernozem, the lower uptake of sorbed $\mathrm{N}$ was not compensated by higher retention in soil and this may indicate that gaseous losses may have been higher in this soil. The chernozem has both higher organic matter content and somewhat higher $\mathrm{pH}$ than the sandy soil, both of which promote microbial activity and nitrification. The addition of zeolite to the soil could have effect on microbial biomass and activity. He et al. [36] found only a small effect when only zeolite was added, but a large effect when also a carbon source (cellulose) was added, supporting that there is an interaction between carbon content and zeolite effect on microbial growth.

\section{Conclusions}

The results indicate that not all $\mathrm{N}$ added sorbed to the zeolite was available to the plants, at least not in the first growth cycle. Our data suggested that some of the $\mathrm{N}$ was tightly bound to (or inside) the sorbent that the plant cannot access it. We think this is the first study to compare plant availability of ammonium added sorbed to ammonium added conventionally. Further research should aim to elucidate how plant availability depends on sorption parameters (capacity, kinetics, and isotherms) and surface properties to try to identify sorbents that can both sorb nutrients efficiently from wastewater and release them when plants need them.

Supplementary Materials: The following are available online at http:/ /www.mdpi.com/2073-4395/9/3/122/s1, Table S1: Chemical and physical characteristics of the soils used.

Author Contributions: Conceptualization: B.F. and M.M.; methodology: B.F.; investigation, E.A. and J.S.; writing - original draft preparation: B.F. and M.M; writing-review and editing: M.M. and B.F.; project administration: B.F. and M.M.; funding acquisition: B.F., M.M., and E.A.

Funding: This research was funded by EEA Norway grant HU09-0096-A2-2016 for Hungary-Norway cooperation.

Acknowledgments: The authors wish to thank Jan Erik Jacobsen, Monica Fongen and Pierre Andrien Rivier for technical assistance.

Conflicts of Interest: The authors declare no conflict of interest. 


\section{References}

1. Hoornweg, D.; Bhada-Tata, P.; Kennedy, C. Environment: Waste production must peak this century. Nature 2013, 502, 615-617. [CrossRef] [PubMed]

2. Metha, C.M.; Khunjar Nguyen, V.; Tait, S.; Bastone, D.J. Technologies to recover nutrients from waste streams: A critical review. Crit. Rev. Environ. Sci. Technol. 2015, 45, 385-427.

3. Crini, G.; Badot, P.-M. Sorption Processes and Pollution: Conventional and Non-Conventional Sorbents for Pollutant Removal from Wastewaters; Presses universitaires de Franche-Comté: Besançon, France, 2010.

4. Estevez, M.M.; Sapci, Z.; Linjordet, R.; Morken, J. Incorporation of fish by-product into the semi-continuous anaerobic co-digestion of pre-treated lignocellulose and cow manure, with recovery of digestate's nutrients. Renew. Energy 2014, 66, 550-558. [CrossRef]

5. Guaya, D.; Hermassi, M.; Valderrama, C.; Farran, A.; Cortina, J.L. Recovery of ammonium and phosphate from treated urban wastewater by using potassium clinoptilolite impregnated hydrated metal oxides as N-P-K fertilizer. J. Environ. Chem. Eng. 2016, 4, 3519-3526. [CrossRef]

6. Guaya, D.; Hermassi, M.; Valderrama, C.; Gibert, O.; Moreno, N.; Querol, X.; Batis, N.H.; Cortina, J.L. Recovery of nutrients (N-P-K) from potassium-rich sludge anaerobic digestion side-streams by integration of a hybrid sorption-membrane ultrafiltration process: Use of powder reactive sorbents as nutrient carriers. Sci. Total Environ. 2017, 599-600, 422-430.

7. Hollister, C.C.; Bisogni, J.J.; Lehmann, J. Ammonium, Nitrate, and Phosphate Sorption to and Solute Leaching from Biochars Prepared from Corn Stover (Zea mays L.) and Oak Wood (Quercus spp.). J. Environ. Qual. 2012, 1, 137-144.

8. Kucic, S.; Cosic, I.; Vukovic, M.; Briski, F. Sorption kinetic studies of ammonium from aqueous solution on different inorganic and organic media. Acta Chim. Slov. 2013, 60, 109-119. [PubMed]

9. Mazeikiene, A.; Valentukrvicirne, M. Removal of ammonium ions from digested sludge fugate by using natual zeolite. J. Environ. Eng. Landsc. Manag. 2016, 24, 176-184. [CrossRef]

10. Takaya, C.A.; Fletcher, L.A.; Singh, S.; Anyikude, K.U.; Ross, A.B. Phosphates and ammonium sorption of biochar and hydrochar from different wastes. Chemosphere 2016, 145, 518-527. [CrossRef] [PubMed]

11. Taghizadeh-Toosi, A.; Clough, T.J.; Sherlock, R.R.; Condron, L.M. A wood based low temperature biochar captures $\mathrm{NH}_{3}-\mathrm{N}$ generated from ruminant urine-N, retaining its bioavailability. Plant Soil 2012, 353, 73-84. [CrossRef]

12. Arcoya, A.; Gonzales, J.A.; Travisio, N.; Seoane, X.L. Physiochemical and catalytic properties of a modified natural zeolite. Clay Min. 1994, 29, 123-131. [CrossRef]

13. Chu, P. The deammoniation reaction of ammonium Y zeolite. J. Catal. 1976, 43, 346-352. [CrossRef]

14. Clough, T.J.; Condron, L.M.; Kamman, C.; Muller, C. A review of Biochar and Soil Nitrogen Dynamics. Agron 2013, 3, 275-293. [CrossRef]

15. Knowles, O.A.; Robinson, B.H.; Contangelo, A.; Clucas, L. Biochar for mitigation of nitrate leaching from soil amended with biosolids. Sci. Total Environ. 2011, 409, 3206-3210. [CrossRef] [PubMed]

16. Lehmann, J.; Joseph, S. Biochar for Environmental Management: Science and Technology; Earthscan: London, UK, 2009.

17. Lehmann, J.; da Silva, J.P.; Steiner, C.; Nehls, T.; Zech, W.; Glaser, B. Nutrient availability and leaching in an archaeological Anthrosol and a Ferralsol of the Central Amazon basin: Fertilizer, manure and charcoal amendments. Plant Soil 2003, 249, 343-357. [CrossRef]

18. Major, J.; Rondon, M.; Molina, D.; Riha, S.J.; Lehmann, J. Maize yield and nutrition during 4 years after biochar application to a columbian savanna oxisol. Plant Soil 2010, 333, 117-128. [CrossRef]

19. Spokas, K.A.; Cantrell, K.B.; Novak, J.M.; Archer, D.W.; Ippolito, J.A.; Collins, H.P.; Boateng, A.A.; Lima, I.M.; Lamb, M.C.; McAloon, A.J.; et al. Biochar: A Synthesis of Its Agronomic Impact Beyond Carbon Sequestration. J. Environ. Qual. 2012, 41, 973-989. [CrossRef] [PubMed]

20. Liang, B.; Lehmann, J.; Solomon, D.; Kinyangi, J.; Grossman, J.; O’Neill, B.; Skjemstad, J.O.; Thiesa, J.; Luizãoc, F.J.; Petersen, J.; et al. Black carbon increases cation exchange capacity in soils. Soil Sci. Soc. Am. J. 2006, 70, 1719-1730. [CrossRef]

21. Zheng, J.; Stewart, C.E.; Cotrufo, F. Biochar and nitrogen fertilizer alters nitrogen dynamics and greenhouse gas fluxes from two temperate soils. J. Environ. Qual. 2012, 41, 1361-1370. [CrossRef] [PubMed] 
22. Szegi, T.A.; Czibulya, Z.; Makadi, M.; Gal, A.; Tombacz, E. Improvement of physical and chemical properties of Hungarian sandy soils by adding organic and inorganic amendments. In Proceedings of the 19th World Congress of Soil Science, Soil Solutions for a Changing World, Brisbane, Australia, 1-6 August 2010; pp. 10-13.

23. Makádi, M.; Henzsel, I.; Lazányi, J. Application of bentonite in agriculture. In Proceedings of the Conference of "Agrárgazdaság, vidékfejlesztés és agrárinformatika az évezred küszöbén (AVA)", Debrecen, Hungary, 1-2 April 2003. (In Hungarian with English summary)

24. Makadi, M.; Tomocsik, A.; Oroz, V.; Bogdanyi, Z.; Biro, B. Effect of biogas-digestate and bentonite on some enzyme activities of the amended soil. Cereal Res. Commun. 2007, 35, 741-744. [CrossRef]

25. Nakhli, S.A.A.; Delkash, M.; Bakhshayesh, B.E.; Kazemian, H. Application of zeolites for sustainable agriculture: A review on water and nutrient retention. Water Air Soil Pollut. 2017, 228, 464. [CrossRef]

26. Guaya, D.; Valderrama, C.; Farran, A.; Sauras, T.; Cortina, J.L. Valorisation of N and P from waste water by using natural reactive hybrid sorbents: Nutrients $(\mathrm{N}, \mathrm{P}, \mathrm{K})$ release evaluation in amended soils by dynamic experiments. Sci. Total Environ. 2018, 612, 728-738. [CrossRef] [PubMed]

27. Li, J.; Wee, C.; Sohn, B. Effect of ammonium- and potassium-loaded zeolite on kale (Brassica alboglabra) growth and soil properties. Am. J. Plant Sci. 2013, 4, 1976-1982. [CrossRef]

28. Li, Z.; Zhang, Y.; Li, Y. Zeolite as slow release fertilizer on spinach yields and quality in a greenhouse test. J. Plant Nutr. 2013, 36, 1496-1505. [CrossRef]

29. Perrin, T.S.; Drost, D.T.; Boettinger, J.L.; Norton, J.M. Ammonium-loaded Clinoptilolite: A slow-release nitrogen fertilizer for sweet corn. J. Plant Nutr. 1998, 21, 515-530. [CrossRef]

30. Taghizadeh-Toosi, A.; Clough, T.J.; Sherlock, R.R.; Condron, L.M. Biochar adsorbed ammonia is bioavailable. Plant Soil 2012, 350, 57-69. [CrossRef]

31. NIBIO. Gjødslingshåndbok (Fertilizer Handbook). Norwegian Institute for Bioeconomy Reseach. 2016. Available online: http:/ / www.bioforsk.no/ikbViewer/page/prosjekt/lenker?p_dimension_id=19190\&p_ $\operatorname{dim} 2=15837$ (accessed on 8 January 2017).

32. Ericsson, T. Growth and shoot:root ratio of seedlings in relation to nutrient availability. Plant Soil 1995, 168/169, 205-214. [CrossRef]

33. Hilbert, D.W. Optimization of plant root: Shoot ratios and internal nitrogen concentration. Ann. Bot. 1990, 66, 91-99. [CrossRef]

34. Ågren, I.G.; Franklin, O. Root: Shoot ratios, optimization and nitrogen productivity. Ann. Bot. 2003, 92, 795-800. [CrossRef] [PubMed]

35. Brookes, P. The soil microbial biomass: Concept, Measurement and applications in soil ecosystem research. Microb. Environ. 2001, 16, 131-140. [CrossRef]

36. He, Z.L.; Calvert, D.V.; Alva, A.K.; Li, Y.C.; Banks, D.J. Clinoptilolite zeolite and cellulose amendments to reduce ammonia volatilization in a calcareous sandy soil. Plant Soil 2002, 247, 253-260. [CrossRef] 